Goldschmidt 2021 Abstract

https://doi.org/10.7185/gold2021.5764

\section{Komatiite melts detect deep hydrous reservoirs in the mantle transition zone implying active subduction since Eoarchean time}

\author{
ALEXANDER V. SOBOLEV ${ }^{1,2}$, EVGENY V. ASAFOV $^{3}$, \\ ANDREY A. GURENKO ${ }^{4}$, CHARBEL KAZZY ${ }^{1}$, ANDREW C. \\ KERR $^{5}$, ALEKSANDR V. CHUGUNOV ${ }^{1}$, VALENTINA G. \\ BATANOVA $^{1,3}$, MAXIM V. PORTNYAGIN ${ }^{6}$, STEPHAN V. \\ SOBOLEV $^{7,8}$ AND JOHN W. VALLEY ${ }^{9}$ \\ ${ }^{1}$ Université Grenoble Alpes \\ ${ }^{2}$ Institute of Earth Sciences (ISTerre), University Grenoble Alpes \\ ${ }^{3}$ Vernadsky Institute of Geochemistry and Analytical Chemistry \\ RAS \\ ${ }^{4}$ Centre de Recherches Pétrographiques et Géochimiques \\ (CRPG) \\ ${ }^{5}$ Cardiff University \\ ${ }^{6}$ GEOMAR Helmholtz Centre for Ocean Research Kiel \\ ${ }^{7}$ GFZ German Research Centre for Geosciences \\ ${ }^{8}$ University of Potsdam \\ ${ }^{9}$ University of Wisconsin-Madison \\ Presenting Author: alexander.sobolev@univ-grenoble-alpes.fr
}

The ERC Synergy project: Monitoring Earth Evolution Through Time (MEET) started in November 2020. Here we report results of study of melt inclusions and host high-Mg olivine phenocrysts of komatiites and related picrites from Phanerozoic localities: Gorgona, Colombia $(0.09 \mathrm{Ga})$, Song Da, Vietnam (0.26 Ga), and Archean localities: Belingwe belt, Zimbabwe (2.67 Ga), Abitibi belt, Canada (2.70 Ga) and Barberton belt, S. Africa (3.3 Ga). Melt inclusions were remelted at $1250-1400{ }^{\circ} \mathrm{C}$ and 1 bar pressure, quenched and studied by EPMA for major elements, $\mathrm{K}$ and $\mathrm{Cl}$, by SIMS for $\mathrm{H}_{2} \mathrm{O}$ contents and $\mathrm{D} / \mathrm{H}$ ratios, and by LA-ICP-MS for trace elements. Host olivines were studied for major and minor elements by EPMA and trace elements by LA-ICP-MS.

Results:

1.Crystallization temperatures using Al-in olivine-spinel and $\mathrm{Sc} / \mathrm{Y}$ olivine-melt geothermometers were up to $1490^{\circ} \mathrm{C}$ for Phanerozoic komatiites and up to $1550^{\circ} \mathrm{C}$ for Archean ones. These correspond to potential temperatures of ca. $1620^{\circ} \mathrm{C}$ and over $1700^{\circ} \mathrm{C}$ correspondingly.

2. Studied inclusions in the most $\mathrm{Mg}$-rich olivines of each suite contain a significant excess of $\mathrm{H}_{2} \mathrm{O}$ over elements of similar partition behavior between solid and melt: $\mathrm{K}$ and $\mathrm{Ce}$. This leads to exceptionally high ratios of $\mathrm{H}_{2} \mathrm{O} / \mathrm{K}_{2} \mathrm{O}$ (up to 40 over normal 1 for OIB and MORB) and $\mathrm{H}_{2} \mathrm{O} / \mathrm{Ce}$ (up to 7000 over normal 200), while $\mathrm{H}_{2} \mathrm{O}$ content is in the range of $0.2-0.9 \mathrm{wt} . \%$ in parental melts.

3. $\mathrm{D} / \mathrm{H}$ ratios of the melt inclusions less affected by $\mathrm{H}$ diffusion loss, indicate mantle source severely depleted in deuterium ( $\delta \mathrm{D}$ is typically in the range between -100 and $-230 \%$ ).
Interpretation:

1. Potential temperature of all studied komatiites exceeds $1600^{\circ} \mathrm{C}$ and thus implies their mantle plume origin. Moreover, these potential temperatures are high enough to ensure partial melting of these plumes when crossing the mantle transition zone.

2. We propose that the mantle plumes that generate komatiites entrain $\mathrm{H}_{2} \mathrm{O}$ by interstitial melt during their passage through the hydrated mantle transition zone.

3. We further suggest that the source of $\mathrm{H}_{2} \mathrm{O}$ depleted in deuterium in the mantle transition zone were subducted partially dehydrated slabs of oceanic lithosphere, which implies an active subduction process since the Eoarchean. 